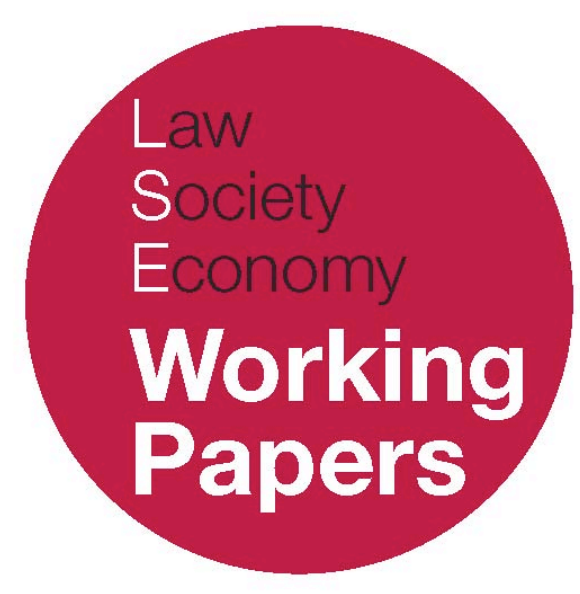

\title{
Inclusivity and the Constitution of the Family
}

\section{Clare Chambers}

LSE Law, Society and Economy Working Papers 2/2009

London School of Economics and Political Science

\author{
Law Department
}

This paper can be downloaded without charge from LSE Law, Society and Economy Working Papers at: www.lse.ac.uk/collections/law/wps/wps.htm and the Social Sciences Research Network electronic library at: http://ssrn.com/abstract $=1331372$.

(C) Clare Chambers. Users may download and/or print one copy to facilitate their private study or for non-commercial research. Users may not engage in further distribution of this material or use it for any profit-making activities or any other form of commercial gain. 


\title{
Inclusivity and the Constitution of the Family
}

\author{
Clare Chambers*
}

\begin{abstract}
This paper starts by discussing Alan Brudner's overall project: the project of inclusivity. It argues that the idea of inclusivity is problematic both conceptually and normatively, for three reasons. First, it is not clear that Brudner's aim to provide a unified theory of the liberal constitution is either possible or desirable. Second, Brudner assumes but does not adequately demonstrate the need for public justification of the liberal constitution. Third, Brudner does not sufficiently explain who should have a veto over his final theory. The paper then turns to Brudner's analysis of sex and family, and argues that his position on these matters is one that liberals would reject. In the case of marriage, Brudner's conclusions may be compatible with liberalism but the arguments supporting them are not. In the case of abortion, neither argument nor policy is compatible with liberalism. Either his position requires that we attribute differential status to human persons, in direct contravention of the fundamental equality of moral worth that liberalism accords to all individuals. Or it requires that we override the rights of individuals by asserting that their own self-authorship is less important to them than a symbol of their personal relationship, a judgment that profoundly undermines individual autonomy.
\end{abstract}

\section{INTRODUCTION}

In this paper I focus on chapter 9 of Constitutional Goods, with its analysis of sex and family. In that chapter Alan Brudner uses the constitutional theory that he has developed throughout the book and applies it to two key issues of state regulation: sexual relationships and abortion. The arguments he uses with respect to both issues are novel, and the conclusion concerning abortion is particularly

\footnotetext{
${ }^{*}$ University Lecturer in Philosophy and Fellow of Jesus College, University of Cambridge. This paper is part of a collection of essays examining important aspects of Constitutional Goods (Oxford: Oxford University Press, 2004). It first appeared as a paper presented at a symposium organized by the LSE Legal \& Political Theory Forum and hosted at the London School of Economics on 9-10 May, 2008. I am very grateful to all the participants in that conference for comments, particularly the organisers, Philip Cook and Thomas Poole, and Alan Brudner. A revised version of this article is published in the current issue of the Canadian Journal of Law and Jurisprudence (2009) 1. The organizers, Philip Cook and Thomas Poole, would like to thank both the LSE and the LSE Law Department for supporting this event.
} 
controversial. So there is much to say about those arguments, and discussion of them is the focus of the second half of the paper. But I start with some general remarks on Brudner's project as a whole: the project of inclusivity. It is necessary to discuss the concept of inclusivity not only because it underpins the arguments of chapter 9. The idea of inclusivity is fundamental to Constitutional Goods as a whole, and in the first part of the paper I argue that this idea is problematic both conceptually and normatively.

\section{INCLUSIVITY}

The aim of Constitutional Goods is to provide an inclusive or integrated theory of the liberal constitution. Brudner intends the theory to be integrated in two senses: by combining all that is best about competing approaches to liberal constitutionalism, and by being acceptable to those who adhere to alternative, more parochial theories of the liberal constitution. These intentions are very important since they set out criteria for success. It is not Brudner's aim to develop a theory that is objectively or universally true. ${ }^{1}$ It is also not his aim to develop a theory that simply repeats the principles that are already accepted in any particular society. ${ }^{2}$ Moreover, Brudner does not intend to put forward a theory that is acceptable to all in the sense of fitting easily with intuitions or established practice: some of his proposals, he warns us, will be 'controversial, and some will overturn what, in some jurisdictions, seems to be settled.'3

Instead, the aim of Constitutional Goods is to develop a theory that explains which principles are really behind the diverse constitutions of various liberal democracies. Brudner's idea is that apparently contradictory constitutional laws originated from different versions of the liberal paradigm, and since each paradigm is at heart liberal, they can and must be reconciled. Their reconciliation is not obvious, and this is the work of the constitutional theory at hand. As Brudner puts it, he intends to develop a theory that integrate[s] what, apart from the theory, appears as a practice riven by competing conceptions of fundamental justice conceptions such as liberty, equality, community, and the good life.'4

This task can be made easy, or it can be made difficult. Brudner argues that it is easy to develop a theory integrating competing conceptions of justice if one does so simply 'by filing them down and reinterpreting them until they cohere'. ${ }^{5}$ However, this easy approach is inadequate since 'no one [resulting conception of justice] will appear adequate in this respect to its rivals. Rather, the conception of

1 According to Brudner, the development of an objectively true theory was the aim of political philosophy before, thanks to Rawls' political liberalism, it trampled on the turf of constitutional theory. A. Brudner, Constitutional Goods (Oxford: Oxford University Press, 2007) 2-3.

2 ibid, 15-16.

3 ibid, 16

4 ibid, 16.

5 ibid, 16. 
justice best qualified to guide liberal practice must integrate these principles as they are respectively understood by their animating moral outlooks - liberal, egalitarian, communitarian, and perfectionist - each of which gives pride of place to only one of these principles.' ${ }^{6}$ Brudner's aim is therefore to come up with a unifying theory that is at once currently obscure and even controversial, but which at the same time manages not only to combine the competing versions of liberalism that underpin all liberal constitutions, but also to do so in a way that 'appears adequate' to all competitors. Here is a task that is very difficult indeed, and I am not convinced that Brudner has accomplished it.

What are the problems? I will mention three. First, Brudner assumes but does not adequately demonstrate that the task is both possible and desirable. He assumes, that is, that the various principles of diverse liberal constitutions can be reconciled, and he assumes that they should be reconciled. Consider, for example, his remarks on the title of his book: Constitutional Goods rather than Constitutional Right or somesuch. Brudner justifies his reference to "goods" by referring to the constitutions of Germany, Canada and South Africa, each of which require that certain goods be provided to citizens (that is, they do not restrict themselves to securing individual rights, or justice narrowly conceived). Brudner comments: 'Unless we are prepared to see these provisions as marking deformities of the liberal constitution, we need a theory of liberal justice that can account for the constitutional status of some goods while preserving intact the more traditional protections of individual rights. ${ }^{7}$ It is taken as read that we are not prepared to see the diverse laws of three very different states as "deformities". But why should we refuse to see them in this way? The word "deformities" implies disapproval or failure, but why should we assume that the constitutions of Germany, South Africa and Canada can be justified according to one unified philosophical theory, and why should we be concerned if they cannot?

Brudner might reply that in writing Constitutional Goods he has thereby demonstrated that a unified constitutional theory can be developed: it can be done because he has done it. Such a response does not explain what is desirable about such a theory, and nor is it adequate to show that a unified theory is possible in the sense I mean. Presumably what is of interest to Brudner (and his audience) is not simply some way in which diverse constitutional theories and practices might be unified, but rather a principle of unification that tells us something significant and relevant about the liberal constitution. By 'significant' I mean something like non-obvious: an insignificant way of unifying diverse constitutional practices might be 'they are all forms of law'. Brudner's theory is certainly non-obvious. By 'relevant' I mean that a theory of unification should be apposite to the purpose for seeking it: I take Brudner's purpose to be political-philosophical, which is to say that he wants to find a normative theory that can justify the different constitutional

6 ibid, 16. Emphasis in the original.

7 ibid, 21. 
elements (as opposed to a unifying historical account, for example). But not all ways of unifying separate phenomena are relevant to a particular purpose.

To see this, consider the question 'what unifies a frog, a newt and a toad?' There are many possible answers to this question. For example: 'they are all greenish-brown'; 'they are all animals'; 'they are all amphibians'; 'they are all things I am afraid of. Which of these is the right answer? It depends on our purpose in asking. The first answer might be of most interest to someone wanting to paint a greenish-brown picture. The second answer is best if we are trying to distinguish animals from vegetables, whereas the third answer is apposite if we are attempting to classify different animals. Finally, the fourth answer is helpful if you are cleaning my house for me and want to know what to leave and what to eject.

But we soon get into trouble if we mix these explanations up, for then we risk coming up with a unifying feature that does not match the purpose we have. Imagine that you are trying to decide what to eject from my house while cleaning it, and you remember that I have previously requested that any frogs, newts and toads be removed. If you wonder to yourself 'what unifies those things?', conclude 'they are all a greenish-brown colour' and act accordingly, you will mistakenly eject my much beloved olive green jumper (something of which I am not the least bit afraid), and you will fail to eject the hairy red-and-black tarantula (something of which I am enormously afraid). So you will have succeeded in coming up with a unifying feature of those things which I have previously ejected from my house, but it is not the relevant feature for your purpose and it is not helpful to have noted it. Brudner's inclusive theory could be like this: it could be that he has succeeded in coming up with a set of principles which have some relationship to a variety of liberal constitutions, but which pick out the wrong features of those constitutions as significant and which thereby wrongly identify those features which are central and those which are peripheral.

The problem could be deeper. The fact that you have come up with a principle that successfully unifies frogs, toads and newts does not mean that there is any shared feature that is relevant for our purposes at all. Perhaps I have previously ejected frogs and toads from my house because I am afraid of them, but have ejected newts (of which I am very fond) simply because I believe that my house is not a pleasant living environment for them. If you then ask the question 'what unifies frogs, newts and toads (that can explain why Clare has previously ejected them all from her house)?', you are asking a question that has no answer. There is no reason that explains why I have ejected them all (other than the obvious and insignificant reason 'they are all things that I do not want in my house'). The answer 'they are all things that I am afraid of seems plausible to the observer and would, if true, be a relevant principle and a helpful guide; however, it is false. The answer 'they are all greenish-brown' does indeed unify the three creatures, but it is false as an answer to the question as to why I have ejected frogs, newts and toads, and as such is irrelevant and unhelpful. Brudner's inclusive theory might be like one of these answers. Like the first answer, it might be a normative theory that does indeed provide answers to the question of what is 
justified and what is unjustified in constitutional practice, but it might err in picking out the relevant features of existing liberal constitutions and thus give flawed answers. Or, like the second answer, Brudner's theory might provide a set of principles that do indeed connect varied liberal constitutions (it is true that all constitutions have these features), but it might be a mistake to think that there is anything normatively significant that connects them in this way (the similarities might be the result of historical accident rather than normative principle, for example). Thus Brudner must do more than simply propose a unifying theory: in order to show that it is possible (in a meaningful sense) and desirable to do so, he must show that the theory is significant and relevant (which is to say that it really does pick out principles that are normatively justifiable).

The first problem, then, is that it is not clear that we should be motivated to develop a theory that can do the integrative work that Brudner claims of his. The second problem continues this theme. It is clear that Brudner attaches normative significance to the fact of public agreement, or public reason. What is required of the theory he is developing is not (only) that it should be correct, but that it should be acceptable to those who currently hold any of the competing liberal theories. ${ }^{8}$ This concern for acceptability is what motivates Brudner to take the difficult rather than the easy path of reconciliation, and it is one of his criticisms of political liberalism that it fails to be acceptable to communitarians or libertarians. Brudner wants to develop a theory that does not simply use the ideas of competing liberalism, but rather that uses those ideas 'as they are respectively understood by their animating moral outlooks' (to repeat the quote from above). The aim is 'to develop principles of constitutional law acceptable to all members of a liberal democracy in which several conceptions of fundamental justice compete for the role of ruling conception." The resulting "convergent consensus" must encompass not only the content of the agreement but the process of public reason used to reach it. Everyone must agree with everything.

But why is public justification so important? What is the principle that tells us that the mark of a legitimate constitution is that it can be justified according to all competing liberal interpretations (but not to non-liberal ones)? For one thing, it is unclear how the concern for acceptability can be practically compatible with a theory that promises controversial prescriptions which overturn "settled" practice. More philosophically, it is not clear that the "liberal confidence" that Brudner describes as the defining feature of liberalism, namely a commitment to the final worth of individuals, should be taken to entail a commitment to developing a theory that all people (all liberals) could accept. Believing that individuals are of ultimate moral value is not the same thing as thinking that individuals' judgments about constitutional law are all of equal value, or that agreement between individuals' judgments is the way to reflect the ultimate value of individuals. It is quite compatible with the liberal commitment to the ultimate worth of individuals

8 ibid, 8-9.

9 ibid, 11. 
to think that there are reasons why individuals' judgements about what best reflects that ultimate worth are wrong. ${ }^{10}$ Unless the liberal confidence is reassessed to mean that those who have it are committed to the idea that (all) individuals' judgments are fundamental (a view that would not be shared so widely) I can see no reason to move directly from the liberal commitment to the ultimate worth of individuals to the idea of public justification.

A great more can, and has, been said about the connection between liberalism and public agreement. Many liberals do believe that public agreement is a defining feature of liberalism. But theirs are complex arguments, bringing with them thick and substantive principles that extend far beyond the liberal confidence. It is not enough, then, for Brudner to assert public justifiability as a premise for liberalism without recognising that in doing so he has already controversially answered a great many fundamental questions about first principles.

The third problem with Brudner's approach concerns which doctrines must be reconciled, with each other and with the final integrated theory. What sort of a theorist does one have to be, what sort of doctrine does a citizen have to uphold, in order to be someone whose theory or doctrine needs to be reconciled into the grand constitutional theory that Brudner undertakes? To put it another way: since Brudner's theory must be acceptable to all (liberals), how does one become someone who gets a veto?11

I discern three different answers to this question in Constitutional Goods. Certainly one has to be a liberal, but what does that mean? According to the first answer, in order to get a veto over Brudner's theory one simply has to believe certain things: one has to be a liberal in the sense of affirming "the liberal confidence". According to the second answer, in order to get a veto one has to adhere to a doctrine that is held by a previously or currently powerful political elite (and one way to do this is presumably by being a member of such an elite), so that one's doctrine has underpinned some actually-existing constitutional law. According to the third answer, in order to get a veto over Brudner's theory one has to have a doctrine that has a recognisably distinctive conception of freedom.

The first answer - that in order to get a veto one simply needs to affirm the liberal confidence - is implied by Brudner when he says that his aim is to develop a liberal theory, and that a liberal is someone who shares what he calls "the liberal confidence". The liberal confidence is the view that individuals have final moral worth: there is nothing more ultimate than the individual (although there may be things that are equally ultimate, such as community). As Brudner puts it, 'we... shall be content to leave the liberal confidence as an underived premise and hence

\footnotetext{
${ }^{10}$ For a more detailed argument that liberalism does not require public agreement see C. Chambers and P. Parvin, 'What kind of dialogue do we need? Gender, deliberative democracy and comprehensive values' in J. Browne (ed.), Dialogue, Ethics and Gender Identity (forthcoming); and C. Chambers and P. Parvin, 'Coercive redistribution and public agreement: re-evaluating the libertarian challenge of charity' in M. Matravers and L. Meyer (eds.), Democracy, Equality, and Justice (Routledge, forthcoming).

11 I take it as read that Brudner only intends his theory to be acceptable to all those who do have a reasonable principled disagreement with it; that it is not, in other words, problematic for him if someone refuses to accept it for capricious, insincere or unprincipled reasons.
} 
to speak only to those who share that confidence. ${ }^{12}$ We still need a theory, of course, because it is not clear precisely what is implied by the liberal confidence. The theory involves 'trac[ing] a conceptual path by which the individual person, in order to satisfy its claim to final worth, is driven to richer conceptions of public reason. ${ }^{13}$ All this is to imply that the reconciliatory aims of Brudner's theory are aimed squarely at understanding the true meaning of the liberal confidence.

If this is the case, though, it is by no means clear why Brudner should choose to consider, as separate approaches deserving their own Part of Constitutional Goods, only three doctrines which uphold the liberal confidence: libertarianism, egalitarianism and communitarianism. There are many, many more doctrines that uphold the liberal confidence as Brudner describes it. Feminism and Marxist socialism are two obvious examples, for neither assert that anything has higher worth than the individual. Additionally, Brudner himself notes that the liberal confidence does not exclude utilitarianism although, oddly, he does not consider utilitarianism as one of the approaches that his theory must reconcile tout court or utilitarians as those who must find it acceptable. ${ }^{14}$ Who, then, does not share the liberal confidence? Presumably those who adhere to theistic religions do not since, according to such religions, the worth of individuals is lower than the worth of God and since, for the religious, individuals can and should subordinate themselves (or be subordinated) to God. And yet Brudner himself talks about the value of religion to the liberal constitution, ${ }^{15}$ and there is no obvious reason why religious believers could not be liberals in the political sense, as Rawls argues. In sum, if Brudner's constitutional theory is intended to be acceptable to all those who share the liberal confidence, there are no grounds for his detailed consideration of only libertarianism, liberal egalitarianism (of the Rawls-Dworkin variety) and communitarianism.

The second possible answer to the question of who gets a veto over Brudner's theory focuses on existing law. Brudner states that, on his approach, 'constitutional principles are sifted from pre-existing material ... distinguishing what is ephemeral in constitutional law from what is rationally enduring." 16 Throughout the book he refers to actual case law from different jurisdictions and attempts to reconcile it - for example, when reconciling US and German abortion law. ${ }^{17}$ This suggests that the relevant criterion of success for his theory is whether it successfully integrates actually-existing constitutional law. But this answer also faces problems: either it does not succeed in showing why doctrines such as feminism are not to be considered, since it is possible that feminist principles underpin some constitutional rulings; or it does succeed in excluding such doctrines but merely for the contingent fact that they were not doctrines espoused

\footnotetext{
$12 \mathrm{n} 1$ above, 15.

13 ibid, 15.

14 ibid, 13 n. 24.

15 ibid, 386.

16 ibid, 11.

17 For example, Brudner writes: 'Once [my account of abortion] is explained, the contrasting positions taken by the American and German courts will become explicable'. ibid, 348-9.
} 
by ruling legislative or juridical elites. This latter appeal to authority is at odds with the egalitarian nature of liberalism.

The third possible answer refers to distinctive conceptions of freedom. Brudner writes that the liberal constitution is a unity of several paradigms of justice', each of which have a distinctive conception of 'what it means for an individual agent to be a free, self-actuating end. ${ }^{18}$ This, then, is what highlights libertarianism, communitarianism and liberal egalitarianism as the doctrines which Brudner's theory must satisfy: each has a distinctive account of freedom. Again, however, it is not clear why these are the only doctrines considered in detail with their own Parts: Marx has a distinctive account of 'what it means for an individual agent to be a free, self-actuating end,' and various feminists have argued that feminism does, too. ${ }^{19}$ It is also unclear why different conceptions of freedom should be taken to be the definitive feature of liberal theories: the liberal confidence might just as well suggest that a theory will be relevantly distinct if it has a different theory of what it means to say that the individual has final worth. Alternatively, we could distinguish between different varieties of liberalism, including libertarianism, egalitarianism and communitarianism, according to their different conceptions of equality, community, human nature or flourishing.

To sum up this first section of the paper: it is not entirely clear what the guiding motivation behind Brudner's overall approach is, and therefore it is difficult both to identify why the approach is supposed to be appealing and to assess whether it really is. In turning to my remarks on his discussion of sex and the family, then, I have tried to keep the aim of the overall project in mind but do not always use those aims as the criteria of assessment.

\section{SEX AND THE FAMILY}

In Chapter 9 of Constitutional Goods Brudner sets out how his integrated constitutional theory deals with the thorny issues of sex and family. Two major issues are discussed: first, how is the state to regulate sexual relationships and which such relationships can be tolerated; second, how is the state to regulate abortion? To answer both questions Brudner looks to a Hegelian principle: the liberal constitution should guarantee 'all claims to individual worth that can be objectively validated in a relationship of mutual recognition. ${ }^{20}$ This principle leads Brudner to the following answers to the two questions. First, the state should regulate relationships so as to permit and endorse those that can truly be relationships of equal recognition. This means recognising heterosexual marriage

18 ibid, 29.

19 See, for example D. Coole, 'Constructing and De-constructing Liberty: A Feminist and Poststructuralist Analysis’ (1993) 41(1) Political Studies 83, and N. Hirschmann, The Subject of Liberty: Toward a Feminist Theory of Freedom (Princeton: Princeton University Press, 2003).

20 n 1 above, 332. 
and homosexual relationships, but not polygamous or incestuous relationships. This answer roughly accords with prevailing liberal thinking but, as the next section shows, the reasoning that Brudner uses does not so accord and is profoundly flawed. Brudner's answer to the second question of abortion accords to prevailing liberal thinking in neither reasoning nor conclusion. He concludes that the permissibility of abortion depends not on factors relating to the moral status of the foetus or of the mother, but rather on the nature of the relationship between the parents of the foetus. If the relationship between the parents is casual, incestuous or non-existent (as in a rape or one-night stand), the mother has the right to make an autonomous choice whether to abort the foetus, and can do so simply for reasons of lifestyle, career or preference. On the other hand, if the parents are in a marriage or committed relationship, the foetus takes on a special status and the mother is not permitted to abort unless her life is in danger. ${ }^{21}$ Not only does this answer not accord with liberal orthodoxy, it does not to my knowledge correspond to the position of any group lobbying on abortion. It is therefore surprising to say the least as a position on abortion which is supposed to be, at once, a combination of actually-existing constitutional law, a paradigmatically liberal position, and actually acceptable to all liberals.

In what follows I outline Brudner's reasoning on both matters. Several of the steps of his argument are problematic because insufficiently argued, and I highlight the steps where problems arise. At the end of each section I comment on his conclusions.

\section{MARRIAGE}

The starting-point for the chapter is what Brudner sees as a puzzle: most liberal states want to permit consensual homosexuality but prevent consensual incest and polygamy. The puzzle is that the positions appear contradictory: why are some consensual relationships permitted but others not, even when both deviate from the 'norm' of heterosexual monogamy?22 If we follow a Rawlsian approach,

\footnotetext{
${ }^{21}$ There are various caveats to Brudner's position, particularly that the state must have ensured that the mother has the equal opportunity for self-authorship that is due to her under the liberal constitution. Once these requirements are in place, though, Brudner argues that abortion should be constrained for women in committed relationships: 'if there is (under ideal circumstances) no parental interest short of life and health that could override the good represented by a healthy fetus voluntarily conceived within a committed relationship, then there is nothing upon which a third party could rely to justify his killing it.' ibid, 352. Brudner does not explain what he means by a "voluntary" conception, but the context suggests that a conception is rendered non-voluntary only if the act of intercourse that caused it was non-voluntary since he earlier attributes overriding worth to the foetus of a committed relationship '[e]ven if unwanted'. ibid, 351.

22 The phrase 'even when both deviate from the "norm" of heterosexual monogamy' is implied but not stated in Brudner's account: it is notable that Brudner draws the contrast between polygamy and incest on the one hand and bomosexuality on the other. Of course, the extent to which this position looks puzzling depends completely on what one takes to be the 'norm': why should permitted consensual heterosexuality not be equally puzzling? Brudner does argue (as discussed in this section of the paper) that there are good reasons for taking heterosexual monogamy as the paradigm of ethical life, but this position is the conclusion of his argument. He gives no reason why we should accept it as a premise of the sort that would give rise to an apparent contradiction. If we did not assume such a norm we might be
} 
according to which intimate relationships can be regulated only according to the neutral principles of justice and the need to sustain society over time, Brudner argues that we cannot justify these views. But this fact means that Rawls' approach, not 'our' position on these relationships, is at fault since the former would not 'satisfy Rawls's own test of equilibrium between theoretical reflection and considered convictions. ${ }^{23}$ We should not, Brudner insists, 'require ordinary people to surrender their belief that their moralisms around these matters [homosexuality, polygamy etc] reflect more than folk taboos. ${ }^{24}$ He therefore seeks an argument that can explain our intuition that homosexuality but not incest and polygamy should be permitted, and turns to Hegel as the only successful source of such an argument.

I am not convinced that a Rawlsian reflective equilibrium must rule out a theory of justice that conflicts with the "moralisms" of "ordinary people" - if such moralisms were always final then there would be no need for a theory of justice at all, no grounds for criticism of or change to prevailing prejudice, and no hope whatsoever for any of Rawls' theory since few if any "ordinary people" endorse the difference principle. The reflective equilibrium requires us to abandon those views, however entrenched, that we cannot make compatible with the principles of justice and the underlying liberal values of freedom and equality. Even if prevailing views on the wrongness of incest and polygamy are to be retained, there seem fairly simple Rawlsian (neutral) grounds on which to explain them: polygamy is wrong to the extent that it violates equal opportunity between men and women, denies women their basic liberties, and undermines the family's operation as a school of justice; and incest is wrong to the extent that it harms non-consenting others and undermines the maintenance of society over time, in both cases by producing children with vulnerable genetic compositions. Brudner rejects these liberal arguments simply because they do not precisely reflect prevailing public opinion: they cannot explain what would be wrong with an equality-ofopportunity-promoting 'combination of polygamy and polyandry' or with 'contracepted incestuous sex or bestiality'. ${ }^{25}$ But bestiality seems to me to fall under a different set of concerns about cruelty to animals, and it is by no means clear that the liberal state should make it illegal for individuals to engage in incestuous or non-monogamous relationships. ${ }^{26}$ So this may well be a matter on which reflective equilibrium requires a change to prevailing sexual taboos rather than the principles of justice.

puzzled about why all sexual relationships aren't forbidden, given that incestuous, polygamous, underage and coerced ones are; or we might draw the line somewhere else, for example between monogamous and non-monogamous sexual relationships, regardless of whether they are heterosexual, homosexual, incestuous or underage.

23 ibid, 326

24 ibid, 326

25 ibid, 326.

26 It is a different question whether the liberal state should offer state recognition to such relationships in the form of marriage but, as I argue in Clare Chambers, 'Feminism, Liberalism and Marriage' (unpublished manuscript), state recognition of marriage is problematic for political liberals anyway. 
Nonetheless, we can follow the alternative argument that Brudner presents. In order to do so we might start by asking why the liberal state has any role to play in regulating intimate relationships through mechanisms such as marriage. Brudner's argument on this point runs as follows:

Now, if the liberal constitution counts mutual cold respect between selfsupporting strangers and equal moral membership in Law's hypothetical community as relationships begetting valid rights and duties, then a fortiori it must count as constitutional goods (that governments have a duty to foster) worth-validating relationships between persons intentionally oriented to them. ... [Thus the state] must treat as a common good the stable human associations formed of these persons and their children. ${ }^{27}$

But this argument is a non-sequitur. It simply does not follow from the fact that individuals have state-enforced rights and duties towards others that they must have different, stronger state-enforced rights and duties towards others with whom they are in intimate relationships. There is an enormous literature arguing, in the context of global justice, that the liberal values of freedom, equality and commitment to the individual precisely preclude special obligations that are based on special relationships between people: our obligations towards others, on these accounts, are universal and equal. ${ }^{28}$ The reason that duties between strangers are enforced may have nothing to do with the nature of the relationship between them; therefore, there is no reason why stronger relationships should be the subject of stronger duties. This is not to say that no argument for enhanced obligations between those in particular relationships could be made, ${ }^{29}$ but it is to say that an argument needs to be made rather than assumed.

Moreover, it simply does not follow from the fact of state-enforced duties between strangers that any intimate relationships are common goods that "governments have a duty to foster". Neither step is justified: nothing follows automatically from enforceable duties towards strangers to different duties towards intimates; and nothing follows from our duties towards strangers about the state's role in actively fostering relationships of any kind.

Brudner goes on to explain in more detail why marital relationships merit special status in a liberal society. He approves of Hegel's claim that relationships are fundamental, since 'The individual's isolated existence is ... a defective, incomplete, and unstable existence.'30 This claim is puzzling in the light of the liberal confidence, the claim that it is the individual (not the couple) that is of

\footnotetext{
27 n 1 above, 332.

${ }^{28}$ See, for example, B. Barry, 'Statism and Nationalism: A Cosmpolitan Critique' (1999) in I. Shapiro and L. Brilmayer (eds.), NOMOS (New York University Press) XLI; C. Beitz, Political Theory and International Relations (Princeton: Princeton University Press, 1999); C. Jones, Global Justice: Defending Cosmopolitanism (Oxford: Oxford University Press, 1999); and J. Waldron, 'What is Cosmopolitan?' (2000) 8(2) Journal of Political Philosophy 227.

${ }^{29}$ For such an argument see D. Miller, On Nationality (Oxford: Oxford University Press, 1995).

30 n 1 above, 332.
} 
ultimate moral worth. How can the individual be both of ultimate moral worth and "defective, incomplete, and unstable"?

Brudner argues that the worth of relationships is twofold: relationships have objective value, and they derive value if they result from the autonomous desires of those who are in them. The two sources of value are connected: the objective value of relationships cannot be imposed by the state as an end in itself because it can only be realised through autonomous action. Thus 'the promotion of virtue is now constrained by the right of self-authorship. Expressive instruction rather than vindication through punishment becomes the principal function of laws relating to sexual morality. These laws now serve as signposts guiding sexual desire into the worth-conferring relationships that make up the life sufficient for dignity.' ${ }^{31}$ In other words, the state cannot coerce people into forming intimate relationships because to do so would be to violate the self-authorship that is a crucial part of a life of dignity. But again, Brudner's argument moves too quickly. It does not follow from the fact that relationships of a certain sort are valuable that the state needs to guide individuals towards those relationships. Brudner has not shown why such state action is necessary, nor has he shown why it is legitimate, and nor has he shown why state promotion of relationships of a certain kind is specifically liberal. 32

Nonetheless, Brudner maintains that the state can and should guide sexual desire into worth-conferring relationships, and one crucial mechanism is by regulating and encouraging marriage. According to Brudner, sexual unions in and of themselves are not sufficient for worth, because they do not distinguish human from animal interactions. (This is another unexplained claim: why must an activity be distinctively human if it is to have worth?) Sexual love, Brudner maintains, can do some of the work since in such love 'the lovers treat each other as irreplaceable ends, so that each receives confirmation of his or her special worth within the relationship. Love is therefore a common good and the proximate end of human sexuality. ${ }^{33}$ I cannot see the force of this "therefore": it may be true that love confirms the special worth of the beloved, but we still do not have enough to show that love has the status of a common good that is the appropriate end of state action. Love may be something we each have an individual interest in achieving, and we have this interest in common; but the fact that we each have an interest in love does not make love into a common good, understood as something we have an interest in achieving collectively, and it does not make it into a good that we have an interest in achieving via the state.

From the idea that love is a common good it follows, for Brudner, that 'the public authority is justified in encouraging the integration of sex and love by expressing disapproval of sexual activity abstracted from love to an extent

31 ibid, 334

32 For the argument that state-recognised marriage is incompatible with certain forms of liberalism, particularly political liberalism, and with feminism, see C. Chambers, 'Feminism, Liberalism and Marriage' (unpublished manuscript).

33 n 1 above, 335. 
consistent with self-authorship. ${ }^{34}$ In earlier parts of the book Brudner argues that the principle of self-authorship, so crucial to egalitarian conceptions of justice, cannot be fundamental since it offers no way of accounting for the legal restrictions on pornography that many liberal states impose. He therefore concludes that self-authorship is important but must be constrained by some 'good raised above the various conceptions of the good formed by moral agents and to which the right of self-authorship must therefore defer. ${ }^{35}$ Love has now emerged as one such good: it is a common good, a constitutional good, and one that can override rights such as self-authorship. It follows for Brudner that relationships can be regulated according to the extent to which they express love. Again, why? Even if we grant that marriage is a common good, why does that make it a constitutional good with priority over self-authorship? Brudner makes these claims but does not explain or justify them.

Brudner proceeds to argue that marriage, specifically, is a relationship of special value for the liberal constitution. Romantic love is not sufficient to count as a good since it is dependent on the feelings of the parties involved. Since feelings can change it follows that the affirmation that each lover offers to the other is fickle. It is only marriage, in which the lovers 'publicly commit themselves to honouring each other as determinate individuals' 36 , which confers the permanent mutual recognition that has the status of a common good. Thus Brudner concludes that the liberal state must recognise, regulate and encourage marriage.

We are now in a position to see how Brudner solves the puzzle with which he started, according to which it could not be seen how the liberal state could endorse both heterosexual and homosexual relationships/marriages but not incestuous or polygamous ones. Incestuous relationships cannot be tolerated, on Brudner's account, because they 'cannot achieve consummation in a worthvalidating relationship'. ${ }^{37}$ This way of putting it is rather question-begging; the point seems to be that incestuous relationships are not consistent with selfauthorship since they are not the result of a 'free choice uninfluenced by natural feelings of partiality arising from kinship or affinity'38 and, the reference to consummation suggests, since they cannot result in (healthy) children. Neither point is convincing, however. First, surely many romantic relationships develop as the result of 'natural feelings of partiality arising from ... affinity' between the parties, an affinity that may come from shared tastes, principles or beliefs. It is not clear, then, why affinity should be seen as antithetical to self-authorship. Indeed, second, the strong social norms against incestuous relationships suggest that any parties choosing to engage in them are acting more autonomously than heteronomously. Third, Brudner's account does not explain what is wrong with

\footnotetext{
34 ibid, 335.

35 ibid, 335.

36 ibid, 336.

37 ibid, 336.

38 ibid, 336.
} 
incestuous relationships between relations who did not grow up knowing of their relationship, such as siblings brought up in different families who discover each other only in adulthood. Fourth, basing the ban on incestuous relationships on considerations for the genetic health of any children that might be born is a consideration that does not require Brudner's inclusive conception: both libertarians and egalitarians can condemn at least uncontracepted incest on these grounds by referring to standard and neutral liberal prohibitions on causing harm to nonconsenting others. ${ }^{39}$

What of polygamous relationships? These are inconsistent with love as a common good that generates valid obligations, according to Brudner, because only monogamy can offer the sort of mutual worth-affirmation that has ethical status. If only one party is free to take additional spouses then there is an asymmetry: one person 'becomes a means to the other's honour but receives no special honour in return.' 40 If both partners may marry multiply then 'there is an equality, to be sure, but one of non-recognition; again, no one receives validation for his or her special worth.'41 In other words, the crux of Brudner's critique of polygamy is quite simply the fact that it is not monogamy, rather than its tendency to inequality and specifically the oppression of its female participants. This focus is problematically peculiar for a liberal account: while egalitarian liberals are rightly suspicious of relationships which are highly likely to be oppressive to identifiable participants (women), it is not usually taken to be part of liberalism that the state should promote monogamy as such (and thus condemn egalitarian "open marriages" as well as patriarchal polygynies).

Why are homosexual relationships, in contrast, suitable for state recognition? The answer may look simple: they can be relationships of monogamous love and thus of mutual recognition. But Brudner cautions us to be more careful: it is not straightforward that non-procreative sexual relationships can have common-good status, because it is only in reproduction that the relationship gains a status that is not inward-looking, dependent on the changeable feelings of the lovers. Only a child can be 'the concrete embodiment of the spouses' moral connection that gives ... the spouses the [permanent] worth that marriage is capable of giving them'. ${ }^{42}$ However, Brudner argues that the worth of a child is not the same thing as the worth of biological offspring. Adopted children also confer worth to a relationship, since the child is not significant as a biological unification of the parents but rather as a representation of 'the marriage in which [the parents] each receive their irreplaceable worth.' ${ }^{43}$ What Brudner seems to mean is that the marriage itself is the ethically significant thing, with the child a symptom rather than a cause of its ethical status. As he puts it, 'Accordingly, the good of marriage

39 Of course such arguments, whether put forward by Brudner or by liberals, do face the complexities of the non-identity problem. See D. Parfit, Reasons and Persons (Oxford: Clarendon Press, 1984).

40 n 1 above, 336.

41 ibid, 337.

42 ibid, 338.

43 ibid, 343. 
is open to homosexual couples. This means that their sexual acts are unqualifiedly good when ordered to love and to marriage.' 44 It is unclear how this solves the original problem: that marriage is dependent on the subjective feelings of the spouses and is therefore fickle. It seems that the problem is solved by labelling it a non-problem in the first place: as long as a relationship is "ordered to" marriage it can be the sort of relationship that is a legitimate basis of marriage.

Brudner's position on marriage, then, is similar to that of many egalitarian liberals and some feminists: the state has a role to play in promoting marriage, including of homosexuals, but it should not endorse or possibly even permit incestuous relationships and polygamous ones. However, the justification given for this position is deeply problematic: many steps are asserted rather than adequately argued, and the foundation of the argument in controversial claims about the absolute worth of the monogamous relationship that is embodied in childrearing does not sit easily with either liberal or feminist commitments.

\section{Abortion}

The fact that Brudner's position on marriage is based on principles antithetical to liberal concerns can be seen clearly in the case of abortion, for here the same principles are used to develop a position that no liberal or feminist could support. As described above, Brudner concludes that the ideal liberal constitution would allow women to choose an abortion for reasons of lifestyle or preference if the foetus were conceived from an uncommitted relationship, casual sexual encounter or rape; but that it would forbid a woman in a committed relationship from aborting any resulting foetus unless the pregnancy threatened her life or health (presumably over and above the threats to life and health that all pregnancies pose). The account of the state's role in regulating marriage, described in the previous section, is what leads Brudner to this unusual conclusion. For Brudner, as we have just seen, marriages and committed relationships "ordered to" marriage take on an ethical value of their own, and this ethical value is embodied in any child that the relationship produces.

Brudner claims that a human foetus can have two sorts of value. From the point at which it becomes a person (and it does not matter for our purposes precisely when this occurs) the foetus has rights. When it reaches this stage it cannot be aborted. In addition, the foetus can have value that constrains others' legitimate actions not by being a rights-bearer but by having the status of being a good. This is a status that some foetuses have and others do not. Those that have good status have that status even before they have rights and retain it throughout their lives, and those that lack this status lack it even after they have rights. ${ }^{45}$

A foetus gains good status if and because it 'embodies a uniquely human connection in love and moral commitment through which the partners receive

\footnotetext{
44 ibid, 343.

45 I am grateful to Alan Brudner for clarifying this aspect of his position at the LSE conference.
} 
confirmation for their special worth.'46 Whether the foetus has good status thus depends on the relationship from which it results:

The offspring of an abstractly sexual union represents the good of an impersonal life process owed weak consideration by everyone equally. That of a marriage represents the moral connection between two people who have a special duty to raise it to freedom as to that which makes the child a fitting embodiment of the family wherein each derives personal worth. And, as the German Court held, there appears to be no reason why that duty should not extend right from the appearance of a new life - that is, from the zygote onward. 47

In other words, if it is conceived in a committed relationship then even a non rights-bearing just-fertilised egg has the status of a good, and that status imposes a duty on the woman in whose body it originated to "raise it to freedom". On the other hand, a much older foetus conceived outside a committed relationship has no such status, and may be aborted at will until such time as it has developed sufficiently to become a rights-bearer.

There are a great many objections to this position. Most come from outside Brudner's theoretical framework, which brings into sharp focus the comments made in the first section of this paper about Brudner's general project. But in the remainder of the paper I focus on a line of objection that connects directly with Brudner's approach.

Many liberals and feminists would reject outright the idea that a woman's right to an abortion should vary according to her circumstances. The standard pro-choice position says that a woman's rights - be they described as rights of privacy, of bodily integrity or of autonomy - mean that she should be allowed to abort a foetus before a certain gestation for her own reasons. Any legitimate restrictions on this right, such as forbidding abortions after a certain period of gestation, must apply to all women equally. They represent the time at which the foetus is assumed to have developed to such an extent that it has reached the status of personhood, giving it rights that compete with the mother's.

How might we go about defending an alternative view, according to which abortion is permitted for women in some circumstances but is not permitted for women in different circumstances (but at the same length of gestation)? Imagine a state which permits abortion for some women and not for others, and bases this difference on the circumstances of conception so that foetuses resulting from a rape may be aborted but those resulting from consensual sex may not. The most obvious way to defend these variable abortion rights would be to say that abortion entails weighing up the rights of the mother against the rights of the foetus, and that to force a woman to carry to term a foetus conceived via a rape would be to

46 ibid, 351

47 ibid, 351. 
violate her rights of autonomy, personal integrity, privacy and dignity most severely and could well subject her to significant trauma. In other words, it is most plausible to hold the status of the foetus constant and to say that any variations in the permissibility of abortion result from variations in the importance or weight of the interests and rights that conflict with it. The strangeness of Brudner's position lies in his claim that the ethical status of the foetus depends on the circumstances in which it was brought about. For him, abortion is permitted in cases of rape and casual sex because the foetus so conceived has less worth than one conceived in a marriage. Brudner's approach thus holds the importance of the woman's rights constant but varies the worth of the foetus.

This position is profoundly inegalitarian (and therefore illiberal) since there can be no variation in the foetus as such that can account for its variable worth. For liberal egalitarians all humans have equal moral worth: any variations in the worth that is assigned to their interests can be justified only by pointing to some action that an individual has taken that entails that she has forfeited some right to have her interests considered. A foetus, as a non-agent, can have performed no such actions. There are thus no liberal grounds for treating one foetus as less valuable than another.

We can put the problems that arise from attributing variable status to foetuses in sharp relief by considering some implications of this view that Brudner does not explore. There is nothing in Brudner's account to suggest that the foetus with good status loses this status at birth, or any time thereafter. It follows from his account, then, that not only foetuses but also children and adults have differential status. We all share the rights that derive from our status as persons. But some of us have an additional status: if we were conceived in marriage we also have the status of a constitutional good, a status which brought us immunity from abortion and overrode the rights of our mothers. Those of us who were not conceived in marriage or a committed relationship lacked and continue to lack this status. ${ }^{48}$ The former group have an ethical status - a status recognised by the state and the society that it represents - that the latter do not. So Brudner's account makes distinctions of status that affect not just non-person foetuses, but also full human persons. This is a profoundly inegalitarian and disrespectful position.

Can we derive Brudner's conclusions if we keep the worth of the foetus constant? The argument might run as follows. We start with Brudner's idea that a foetus conceived in a marriage is the embodiment of the value of that marriage which, in turn, comes from the fact that the marriage affirms the worth of each party within it. If we hold the foetus's value constant, then the prohibition on women aborting a foetus conceived within marriage cannot be because such a foetus is more valuable than one otherwise conceived. The additional interests that compete with the woman's right to choose an abortion must therefore come from the value of the marriage to the married couple. If the marriage affirms the worth of

\footnotetext{
48 It is unclear whether, on Brudner's account, a person conceived in marriage loses their status as a good if the marriage ends.
} 
the married individuals, we might say that the interests that oppose abortion are precisely the interests of that couple. Abortion of the foetus is impermissible in such cases (according to this re-formulation of Brudner's position) not because the foetus has a higher status in and of itself than one conceived outside of marriage, but because the value of the woman's right to self-authorship is outweighed by the value to the couple of a symbol of their marriage (a symbol in the form of a foetus).

Why is a foetus a symbol of the marriage? Recall that, as we learned in Brudner's defence of homosexual relationships, the child merely symbolises and is not itself identical with the value of the marriage. According to him, if the child were in itself identical with the value of the marriage then relationships that cannot reproduce would lack ethical status. The claim that the value of the marriage is symbolised by the foetus is mysterious in itself. But even if we accept this idea we are still left with the result that, by forbidding marital abortions, the woman's right of self-authorship is overridden by the value of a symbol of her worth being affirmed - even if she does not herself place the value of the symbol above her own self-authorship. It is not clear what the effects of this ruling will be on her self-worth.

Of course, we must also consider the value of the foetus to the husband (assuming he does not support the abortion). Again, however, the value that Brudner gives to the foetus is only the value of its symbolisation of marriage, and even the husband's interest in a symbol of the affirmation of his worth does not seem a good candidate to override the wife's interests in bodily integrity.

This version of Brudner's position provokes other puzzling questions. ${ }^{49} \mathrm{We}$ have reached the conclusion that there is something so valuable in a couple having a symbol of their marriage that it can override any rights or interests they, and particularly the woman, have in self-authorship and bodily integrity. It is not clear, however, whether this overriding value attaches to having a symbol of their marriage or to having any symbol of their marriage. In other words, do second and subsequent children have the same status as first children? Can a couple ever have sufficient symbols of their marriage, so that there is no need (at least no overriding need) to raise yet another? If a married couple conceives their second, or fifth, or tenth child, does there ever become a point at which the mother's self-authorship interests outweigh the value to her of having yet another symbol of her marriage? More accurately: is she yet in a position to decide for herself whether or not her self-authorship or another symbol of her marriage is more valuable to her?

We might take another tack. If the foetus conceived in a committed relationship has good status because it is a symbol of the relationship from which it results, rather than by having any differential status qua human, we might ask whether other non-human objects may act as symbols in the relevant way. For example, does a work of art (such as a painting or piece of music) that results from

49 I am grateful to the participants in the LSE conference, particularly John Charvet and David Lloyd Thomas, for highlighting these issues. 
and symbolises a committed relationship have good status that prevents it from being legitimately destroyed? Recall that the prohibition on abortion that Brudner wishes to invoke applies to foetuses which do not yet have the status of personhood and which therefore lack rights. Once a foetus becomes a person that very status prevents it from being aborted, whether or not it results from a committed relationship. So it is reasonable to ask whether a painting, also a nonperson that lacks rights, can have the same good status as a foetus. If the answer is "yes" then the oddity of placing the status of a non-person above the fundamentally important rights to self-authorship and bodily integrity of a person is highlighted. Could a liberal really argue that a painting must not be destroyed because of its symbolisation of a relationship (not because of any ownership rights), even if its continued existence somehow restricted an individual's rights? On the other hand if Brudner were to answer "no, a painting cannot have the same status as a pre-person embryo", we are returned to the idea that his restrictions on abortion result from some additional status that the embryo has, a status that both embryos and adult humans have unequally.

\section{CONCLUSIONS}

Brudner's account is problematic, then, in several ways. Its motivation is unclear since liberalism need not entail the sort of inclusivity that he variously suggests. Its results are problematic because, against the spirit of inclusivity, they rest on illiberal accounts of value. As a result his position on marriage and abortion is one that liberals would reject. In the case of marriage, Brudner's conclusions may be liberal but the arguments supporting them are not. In the case of abortion, neither argument nor policy is compatible with liberalism. Either his position requires that we attribute differential status to human persons, in direct contravention of the fundamental equality of moral worth that liberalism accords to all individuals. Or it requires that we override the rights of individuals by asserting that their own self-authorship is less important to them than a symbol of their personal relationship, a judgment that profoundly undermines individual autonomy. 